of interchange of teachers ; (4) adult education in the universities. Reports from these sections were presented by the sectional leaders to the Conference for discussion on the last morning.

In general, it may be said that there was abundant evidence of interest in the very varied experiences and opinions revealed in these informal discussions. At a first conference the procedure must obviously be exploratory, but nevertheless there was a movement to set on foot international committees to deal with both of the questions, overcrowding and exchange, in which concerted action seems to be specially indicated.

These committees were not actually instituted by the present Conference, which felt that the ground should be explored further with fuller material in hand before action is taken. In order to prepare for this, the Conference resolved that an International Conference Committee should be instituted and that the university associations in each country, or single national universities where such exist, or ad hoc committees in other countries, be invited to nominate an officer to act as a member of this committee, the duty of which will be to maintain international contacts and prepare material for future conferences. Prof. R. C. McLean of University College, Cardiff, was appointed by the Conference to act as secretary of this committee.

The Conference then agreed to accept provisional invitations from France for 1935 and from Germany for 1936 as the scenes of the next two Conferences.

The Warden and fellows of All Souls gave an evening reception at which the Vice-Chancellor, who was unavoidably absent from Oxford, was represented by the Right Hon. H. A. L. Fisher, the Master of New College. The Conference was concluded by an address from Prof. Gilbert Murray, in which he emphasised the duty of university people to uphold ethical standards and freedom in the pursuit of truth.

The movement thus initiated promises well for the future co-operation between universities in different lands, and it is greatly to be hoped that these periodical conferences will establish themselves as a permanent and valuable feature of international organisation.

\title{
Sixteenth International Congress of Agriculture
}

$\mathrm{T}$ HE sixteenth International Congress of Agriculture was held at Budapest on June 13-20 under the presidency of the Marquis de Vogue, president of the International Commission of Agriculture, and was attended by about 1,100 members. The fifteenth Congress had taken place at Prague in June 1931 and the fourteenth at Bucharest in 1929 , it having been the intention up to the present to convene such gatherings every two years. Actually ten meetings took place prior to the War, and a further six have taken place since. The seat of the international organising committee is at Paris where the inaugural meeting was held in 1895 , to be followed by a second (which actually, however, must rank as the first proper) meeting at Budapest in 1896, which year marked the thousandth anniversary of the existence of Hungary as a nation.

Consequently, after an interval of thirty-eight years, Budapest has been once more chosen as the venue for the Congress. At the preceding one, held at Prague, attention was focused on the then most pressing problem of the moment, namely, the agricultural crisis and methods to be recommended for combating it and minimising its evil effects. The programme of work at the recent Congress was subdivided into eight sections, namely, (1) agricultural economics, (2) rural education, (3) co-operation, (4) crop production, (5) viticulture, (6) live-stock production, (7) agricultural industries and (8) con. sideration of the part played by women in the farming community and in farming life.

The principal paper in section 1 was that by Prof. Ernest Laur, director of the Union suisse des paysans, on the reorganisation of present-day agriculture and, in view of the persistence of the agricultural depression in almost all countries of the world as well as the severity of its incidence, the subject of his contribution must be considered as the principal and most important topic discussed at this Congress. Prof. Laur, at the conclusion of his paper, put forward various recommendations, forming part of a proposed agricultural policy, amongst which were that the consumption of fats of animal origin, and especially butter, should be encouraged by private or State measures in order to combat the growing consumption of vegetable fats, which in turn has restricted the consumption of cereals and been one of the principal causes of the accumulation of cereal stocks with resulting price debasement.

The other papers in section 1 dealt with the in fluence of mechanisation on agriculture and with the organisation of a proposed international live-stock market.

At the Prague Congress the attendance was about 1,200, including 563 participants from European countries other than Czecho-Slovakia and from nonEuropean countries, and this total represented the highest attendance reached at any meeting held up to date. The Budapest Congress showed an attendance of 72 official delegates of various Governments, 19 delegates representing international organisations, and about 1,028 individual members. Great Britain was only represented by some fifteen of the latter and such a poor representation is, in the opinion of the writer of this article, very much to be regretted, the more especially as the same state of affairs prevailed at the two previous congresses at Bucharest and Prague.

Most of the countries taking part in these congresses are, in the main, agricultural exporting countries, whereas England is, as is well known, a heavy importer of agricultural produce. In order therefore that her views and difficulties as such should be properly stated and justified, it is essential that she should be adequately represented at these international congresses, which assume more and more importance as time goes on. Failure to do so is liable to result in judgment going by default.

At the termination of the Congress a choice of agricultural excursions was offered to all members, that to the Hungarian university town of Szeged and to the Government stud farm at Mezöhegyes being of especial interest.

At the closing session the Congress resolved that from now onwards meetings should be held at intervals of three instead of two years, as previously intended, and that the venue for the next congress should not be decided until next year. 